\title{
Hydrogeological Characterization of the Gunungsewu Karst Area in the Upper Reach of Gremeng Karst Drainage Basin, Indonesia
}

\author{
Ahmad Cahyadi ${ }^{1,2^{*}}$, Tjahyo Nugroho Adji ${ }^{1,2}$, Eko Haryono $^{1,2}$, and Margaretha Widyastuti ${ }^{1,2}$ \\ ${ }^{1}$ Karst Research Group, Faculty of Geography, Universitas Gadjah Mada, Yogyakarta, Indonesia \\ ${ }^{2}$ Department of Environmental Geography, Faculty of Geography, Universitas Gadjah Mada, Yogyakarta, Indonesia
}

\begin{abstract}
The definition of a karst drainage basin in the aquifer of the karst area is an absolute thing to do as a water resource management unit. This research aimed to characterize the hydrogeology of the Gunungsewu Karst Area in the upper reach of the Gremeng Karst Drainage Basin. For this purpose, it was divided into three stages, namely geological survey, speleological survey, and artificial tracer test. The results indicate that the area observed lies in two or more geological formations: Semilir Formation, composed of sandstone and tuff from the ancient volcano Wonodadi eruptions, and Wonosari Formation, in which carbonate rocks consisting of massive coral limestone and bedded chalky limestone predominate. In volcanic rocks, the surface rivers have developed into allogenic streams flowing from underlying beds exposed updip. The contact between the two different formations results in the formation of ponors and springs. The artificial tracer test revealed two underground river systems with single conduits controlled by the allogenic rivers and large slope gradients in the study area.
\end{abstract}

\section{Introduction}

Following the groundwater basin's conceptual development in hydrogeology in the 1960s, karst hydrologists/hydrogeologists began to draw attention to the conceptualization and investigation of a karst drainage basin [1]. However, scholars have termed karst drainage basins as, among others, karst catchment areas, karst watersheds, springsheds, hydrogeological systems, karst basins, and underground river systems to date. Each refers to a definition of the basin as surface and subsurface areas that recharge an underground river, conduit, or spring in a karst landscape [2].

In-depth knowledge of a karst drainage basin is pivotal in understanding local water resource potentials and characteristics. Karst drainage basins with known extent and boundaries make all relevant hydrological analyses possible, especially related to the water balance of a karstic system [3,4]. Karst drainage basins with known extent and boundaries make all relevant hydrological analyses possible, especially related to the water balance of a karstic system [5,6]. However, determining the basins is more complicated and takes a longer time than delineating surface watersheds [7]. Some of the reasons include topographical and hydrological features that often have mismatched boundaries, variable groundwater tables during the rainy or dry season, dissolution tunnels with varying developments over time, many tunnels in an underground river system (e.g., maze cave), and the ease with which subsurface stream piracy occurs in underground rivers or conduits because of cave collapse, earthquakes, or sediment deposition [8,9].

Gunungsewu Karst Area on Java Island is one of the Indonesian karst landscapes with a drainage basin definition that has existed for a long time. Further, the Ponjong Hydrogeological Subsystem makes up the basin's northern and central parts. MacDonalds and Partners started a survey in 1979 and completed their research report in 1984 [10], marking the beginning of karst area definition in the subsystem. However, the results are considered limited-potentially raising conceptual and analytical issues - because the research incorporated the entire Ponjong Hydrogeological Subsystem into the Bribin Karst Drainage Basin despite the absence of any tracer tests in the region's allogenic rivers. Subsequent studies by the Faculty of Forestry, Universitas Gadjah Mada (1993)[11] Adji (2009)[12], Gunawan (2013)[13], and Widyastuti (2014)[14] still include the former as part of the latter.

Cahyadi et al. (2019; 2020)[15,16] divide the northern segment of the Ponjong Hydrogeological Subsystem into two karst drainage basins: Beton and Gremeng, but have not discussed it in detail. Therefore, the current research set out to complement previous studies that merely separated the subsystem's northern part from the Bribin Karst Drainage Basin. It has a specific objective to describe one of the primary stages of defining a karst drainage basin, that is, hydrogeological characterization. For this purpose, it focuses on the upper reach of the Gremeng Karst Drainage Basin, which is located in the northernmost

* Corresponding author: ahmadcahyadi@geo.ugm.ac.id 
part of the Ponjong Hydrogeological Subsystem in the Gunungsewu Karst Area.

\section{Methods}

This research was conducted in the upper reach of the Gremeng Karst Drainage Basin, the northern edge of the Ponjong Hydrogeological Subsystem in the Gunungsewu Karst Area. Administratively, it belongs to Sawahan Village, Ponjong District, Gunungkidul Regency. This location has four allogenic watersheds with streams flowing from outside the karst area: Grembel River, Seropan River, Garuda River, and Kalimati River (Figure 1).

The research method had three stages: geological survey, speleological survey or cave mapping, and artificial tracer test. In the geological survey, the distributions of limestone, allogenic springs, allogenic rivers, catchment areas, and geological structures were mapped. Subsequently, the speleological survey mapped the locations of caves and cave passages (if feasible). The third stage was a tracer test using tracing dyes in solution to determine the connectivity between ponors, sinkholes, or caves with springs or underground rivers in the study area. The artificial tracer test produced breakthrough curves (BTCs) based on the fluorometer readings, the shape of which helps to analyze the characteristics of developed tunnels [17].

\section{Results and Discussion}

The rocks found in the study area can be broadly divided into two groups: volcanic and carbonate (Figure 1). The volcanic rocks consist of sandstone and tuff, which are part of the Semilir Formation deposited 20-16 million years ago in marine and terrestrial environments $[18,19]$. The constituent rocks are likely sourced from the ancient volcano Wonodadi [20]. In locations composed of volcanic rocks, the surface rivers have developed into allogenic streams in the observed karst drainage basin.

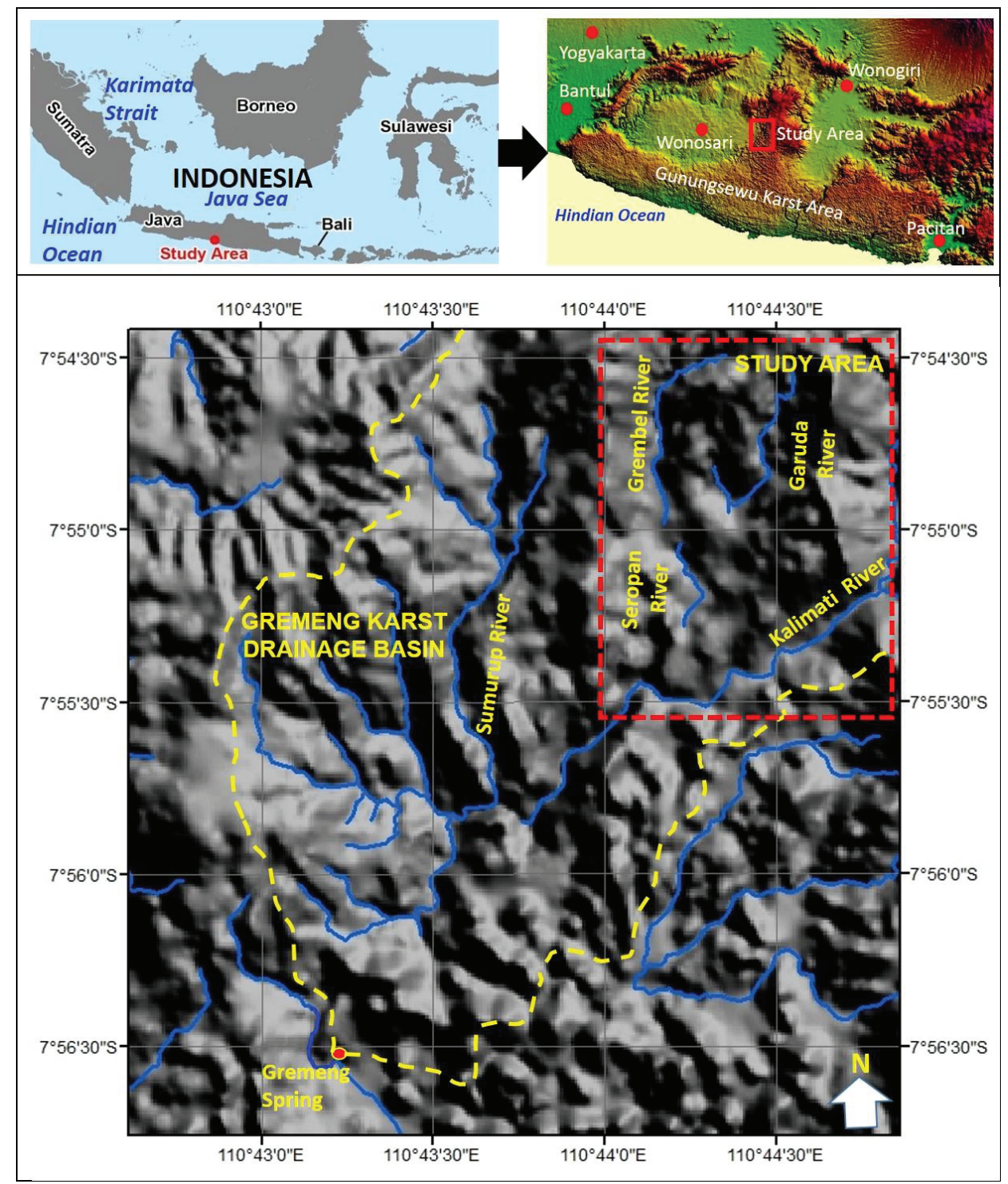

Fig. 1. The Map of Study Area. 
The carbonate rocks making up the study area consist of massive coral limestone and bedded chalky limestone, members of the Wonosari Formation - which was deposited in the post-volcanism period (i.e., the Middle to Late Miocene) or younger than the Semilir Formation. The contact between Wonosari and Semilir Formations results in two hydrogeological formations: ponors through which allogenic rivers enter the underground river system and springs as the output of underground rivers (Figure 2). The allogenic rivers in question are allogenic streams flowing from underlying beds exposed updip [15,21].

The artificial tracer tests were conducted for three locations: Garuda Ponor to Tempuran Spring, Seropan Ponor to Tempuran Spring, and Grembel Ponor to Sutorenggo Spring. The tracer dyes were introduced at the same time at Garuda Ponor, Seropan Ponor, and Grembel Ponor, with the fluorometers installed at Sutorenggo Spring and Tempuran Spring. Because of the simultaneous injection, three tracer dyes were used to provide distinguishable readings after excitation.
The tracer tests revealed that the karst drainage basin observed had two main underground river systems: the system connecting Grembel River - Grembel Ponor Sutorenggo Spring - Seropan River - Seropan Ponor Tempuran Spring (Figure 3) and another system connecting Garuda River - Garuda Ponor - Tempuran Spring (Figure 4). However, without any accessible routes to Tempuran Spring, the speleological survey at this site was not feasible, so that the exact location of the meeting point between the two underground river systems is unknown.

Another result of the artificial tracer test is BTCs, as shown in Figure 5. BTCs of the three locations formed three separate single curves with steep rising and falling limbs, indicating that the conduits developing along the underground rivers have large slope gradients. Similar results were found in the conduit of the Beton Karst Drainage Basin, which shares the same geological characteristics with this research, located at the transition between Semilir and Wonosari Formations and in the same hydrogeological subsystem (i.e., Ponjong Hydrogeological Subsystem)[16].

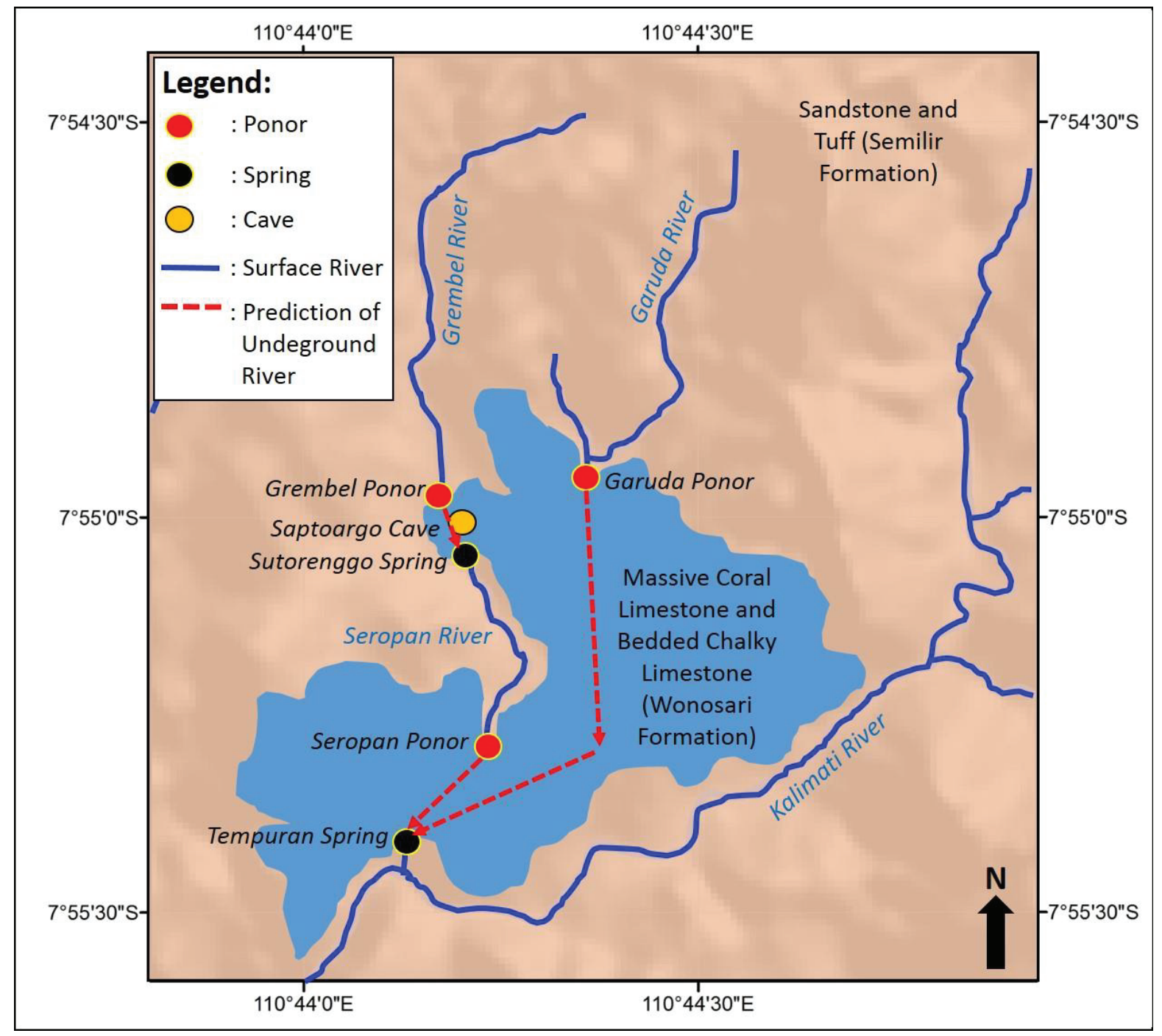

Fig. 2. The Rock Formation Distribution Map and Predition of Underground River Flow Direction in Study Area. 


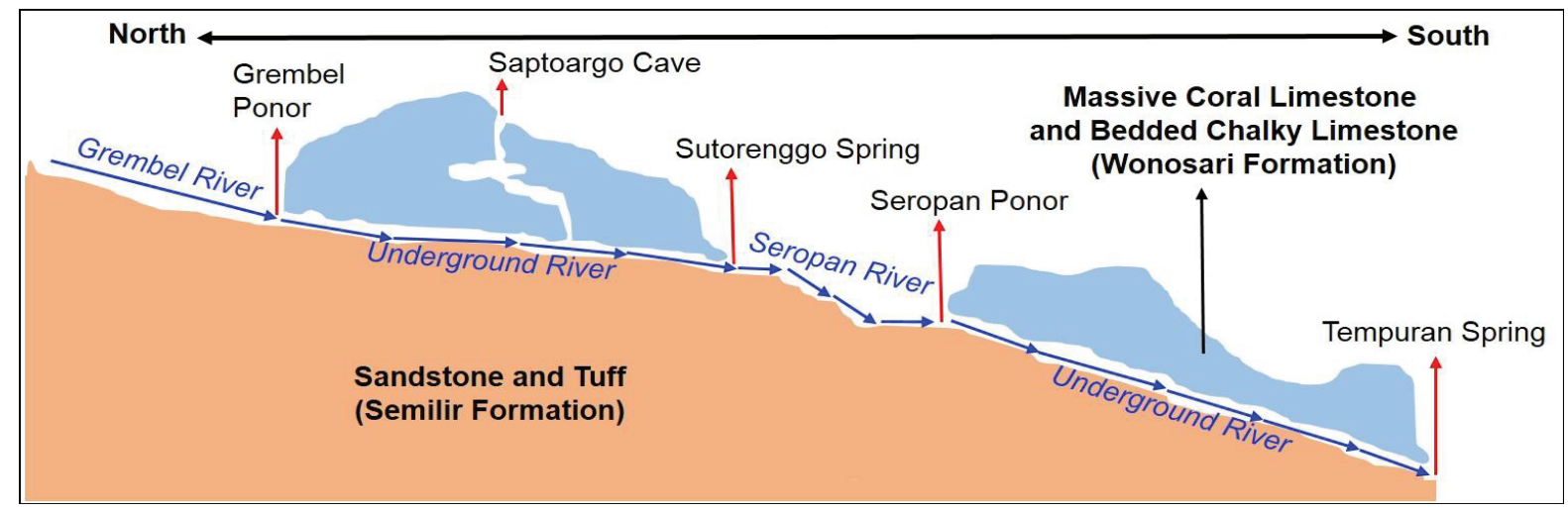

Fig. 3. Scheme of the Underground River System Connecting Grembel Ponor to Tempuran Spring.

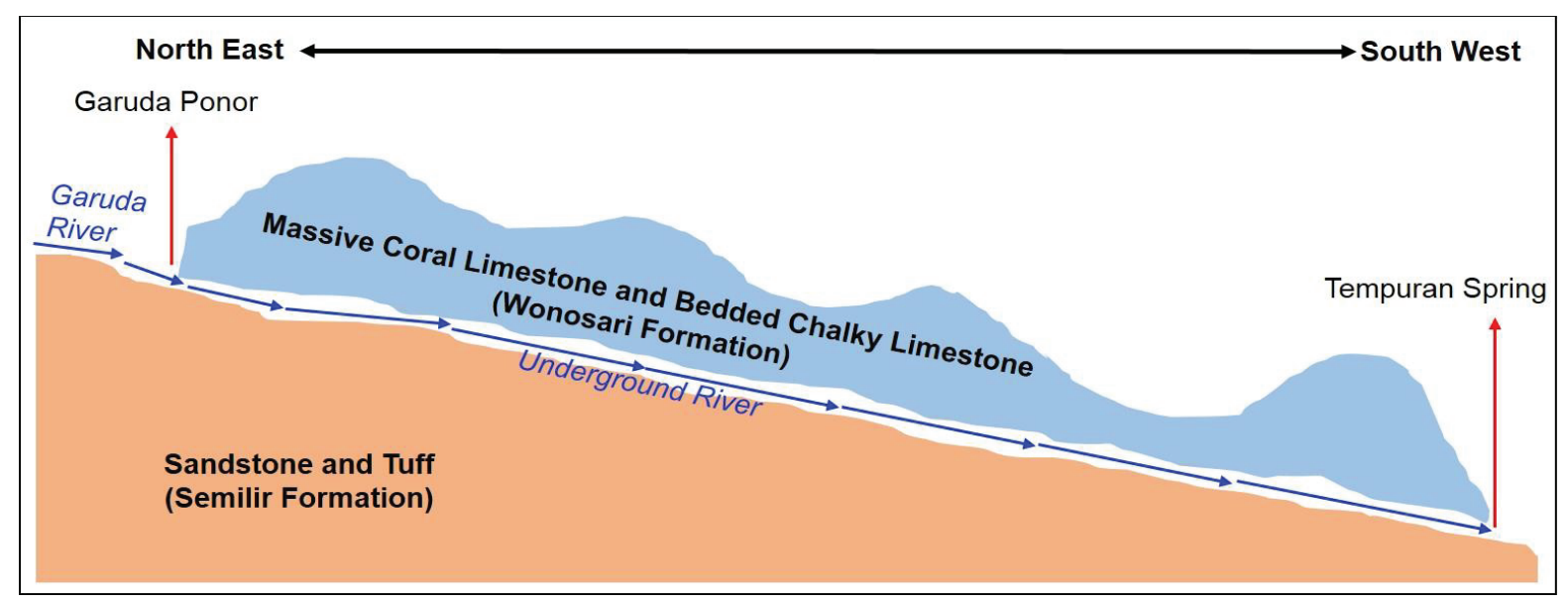

Fig. 4. Scheme of the Underground River System Connecting Garuda Ponor to Tempuran Spring.

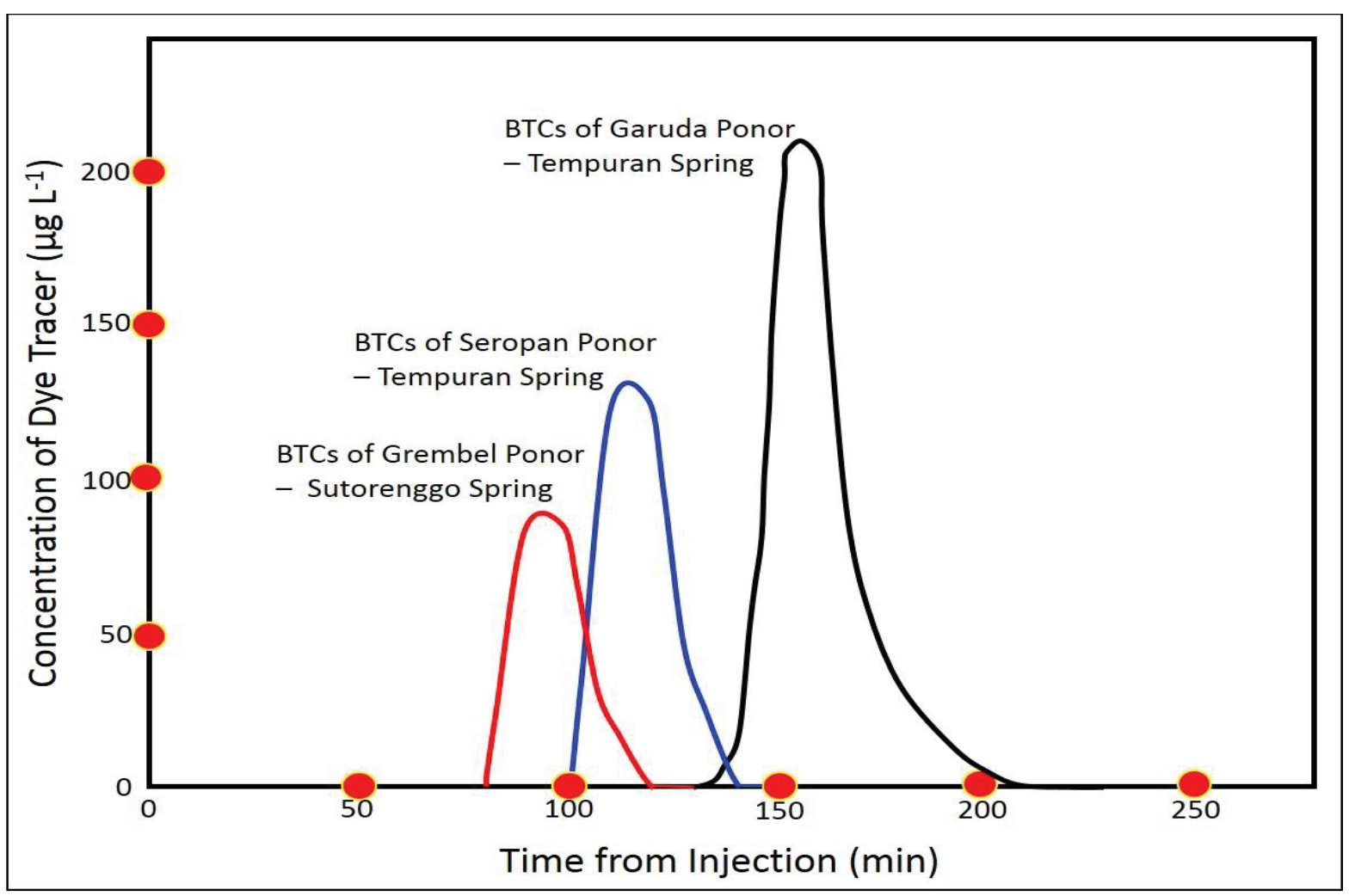

Fig. 5. Breakthrough Curves of the Artificial Tracer Test Results in the Study Area 
Single BTCs also indicate that the three locations have single conduits. As confirmed by Palmer (2001, 2007)[22,23] and Cahyadi et al. (2020)[15], underground river systems affected by allogenic recharge often produce single conduits, especially in areas with a significant difference in elevation.

In this study, no underground river system was identified other than the one that empties into the Tempuran Spring. This is inferred from the absence of other springs as a system output from an underground river. In addition, from all existing ponor and caves in the study location, it has been detected that they have connections with the Tempuran Springs as the main output of the underground river system at the study site.

\section{Conclusions}

The research location consists of two rock formations, namely Semilir Formation (mainly comprising volcanic rocks: sandstone and tuff) and Wonosari Formation (with massive coral limestone and bedded chalky limestone as predominant constituent rocks). The contact zone between the two formations creates allogenic rivers flowing from underlying beds exposed updip. Broadly speaking, the two identified underground river systems merge to form a single system that exits Tempuran Spring. This results in a single conduit, which is a characteristic of a cave formed due to the influence of an allogenic river and a relatively large slope gradient.

\section{Acknowledgments}

This research uses some of the data analyzed and presented in the first author's dissertation in the Geography Study Program, Faculty of Geography, Universitas Gadjah Mada, Indonesia. It received funding from Universitas Gadjah Mada through the Grant Scheme for Final Assignment Recognition Program (Hibah Program Rekognisi Tugas Akhir) in 2021.

\section{References}

1. White, W.B. Fifty Years of Karst Hydrology and Hydrogeology: 1953-2003. In Hormon, R.S. Wicks, C. (eds). Perspectives on Karst Geomorphology, Hydrology and Geochemistry- A Tribute Volume to Derek C. Ford and William B. White. Geological Society of America (2006)

2. Quinlan, J.F. Ewers, R.O. Subsurface Drainage in the Mammoth Cave area. In White, W.B. White, E.L. (eds.) Karst Hydrology Concepts from the Mammoth Cave Area. New York : Van Nostrand Reinhold (1989)

3. Bonacci, O. Jukić, D. Ljubenkov, I. Definition of Catchment Area in Karst: Case of the Rivers Krčić and Krka, Croatia. Hydrological Sciences Journal, 51(4), 682-699 (2006)
4. Widyastuti, M. Riyanto, I.A. Naufal, M. Ramadhan, F. Rahmawati, N. Catchment Area Analysis of Guntur Karst Spring Gunung Kidul Regency, Java, Indonesia. IOP Conrence Series: Earth and Environmental Science, 256 (2019)

5. Chen, X. Sun, Y. Huang, R. Role of Hydrogeochemical Functions on Karst Critical Zone Hydrology for Sustainability of Water Resources and Ecology in Shoutwest China. Acta Geochim, 36(3), 494-497 (2017)

6. Zhang, Z. Chen, X. Cheng, Q. Li, S. Yue, F. Peng, T. Waldron, S. Oliver, D.M. Soulsby, C. Coupled Hydrological and Biogeochemical Modelling of Nitrigen Transport in the Karst Critical Zone. Science of the Total Environment, 732, (2020)

7. Cahyadi, A. Fatchurohman, H. Pratiwi, E.S. Metode-metode Identifikasi Karakteristik Daerah Tangkapan Air Sungai Bawah Tanah dan Mataair Kawasan Karst. In Marfai, M.A. Widyastuti, M. (eds.). Pengelolaan Lingkungan Zamrud Khatulistiwa. Yogyakarta : Penerbit Pintal (2013)

8. Thrailkill, J. The Inner Bluegrass Karst Region. In Dougherty, P.H. (ed). Caves and karst of Kentucky. Kentucky : Geological Survey (1985)

9. Taylor, C.J. Greene, E.A. Hydrogeologic Characterization and Methods Used in the Investigation of Karst Hydrology. In Rosenberry, D.O. LaBaugh, J.W. (eds). Field Techniques for Estimating Water Fluxes Between Surface Water and Ground Water. Virginia: U.S. Geological Survey (2008)

10. MacDonald and Partners. Greater Yogyakarta Groundwater Study. Yogyakarta: Directorate General of Water Resources Development of the Republic of Indonesia (1984)

11. Faculty of Forestry, Universitas Gadjah Mada. Penyusunan Arahan Konservasi Tanah dan Air di Daerah Tangkapan Air Gua Bribin Kabupaten Gunung Kidul, D.I. Yogyakarta. Research Report. Yogyakarta: Forestry Service of Yogyakarta Special Province (1993)

12. Adji, T.N. Variasi Spasial Temporal Hidrogeokimia dan Sifat Aliran untuk Karakterisasi Sistem Karst Dinamis di Sungai Bawah Tanah Bribin Kabupaten Gunungkidul, Daerah Istimewa Yogyakarta. Dissertation. Faculty of Geograpy, Universitas Gadjah Mada (2009)

13. Gunawan, T. Kontribusi Citra Penginderaan Jauh dalam Kajian Batas Daerah Aliran Sungai (DAS) dalam Rangka Pengelolaan Sumber Daya Air (Kasus di Gunungkidul Daerah Istimewa Yogyakarta). Research Report. Faculty of Geograpy, Universitas Gadjah Mada (2013)

14. Widyastuti, M. Kajian Kerentanan Airtanah terhadap Pencemaran di Daerah Karst Gunungsewu (Studi di Daerah Aliran Sungai Bawah Tanah Bribin, Kabupaten Gunungkidul dan Wonogirio. Dissertation. Faculty of Geograpy, Universitas Gadjah Mada (2014) 
15. Cahyadi, A. Haryono, E. Adji, T.N. Widyastuti, M. Riyanto, I.A. Naufal, M. Ramadhan, F. Allogenic River in the Hydrogeological System of Gremeng Cave, Gunungsewu Karst Area, Java Island, Indonesia. IOP Conference Series: Earth and Environmental Science, 448 (2020)

16. Cahyadi, A. Haryono, E. Adji, T.N. Widyastuti, M. Naufal, M. Ramadhan, F. Agniy, R.F. Riyanto, I.A. Analisis Konektivitas dan Karakteristik Lorong pada Sistem Hidrogeologi Mataair Beton, Kawasan Karst Gunungsewu, Kabupaten Gunungkidul dengan Uji Perunutan. Jurnal Geografi, 12(2), 105 - 114. (2020)

17. Cahyadi, A. Agniy, R.F. Analisis Breakthrough Curve untuk Karakteristerisasi Pelorongan di Sistem Sungai Bawah Tanah Pindul Kabupaten Gunungkidul. Proceeding of Pertemuan Ilmiah Tahunan Ke-1 Perhimpunan Ahli Airtanah Indonesia (PIT-PAAI). Bandung, November 16-17, 2016, 375 - 385 (2016)

18. Akmaluddin, Setijadji, D.L. Watanabe, K. Itaya, T. New Interpretation on Magmatic Belts Evolution during the Neogene-Quaternary Periods as Revealed from Newly Collected K-Ar Ages from Central-East Java - Indonesia. Proceeding of Joint Convention IAGI-HAGI-PERHAPI, Surabaya (2005)

19. Surono. Sedimentasi Formasi Semilir di Desa Sendang, Wuryantoro, Wonogiri, Jawa Tengah. Jurnal Sumber Daya Geologi, 28(1), 29-41 (2008)

20. Bronto, S. Mulyaningsih, S. Hartono, G. Astuti, B. Waduk Parangjoho dan Songputri: Alternatif Sumber Erupsi Formasi Semilir di Daerah Eromoko Kabupaten Wonogiri, Jawa Tengah. Jurnal Geologi Indonesia, 4(2), 79 - 92 (2009)

21. Ford D. Williams P.W. Karst Hydrogeology and Geomorphology. Chicester: John Willey and Sons (2007)

22. Palmer, A.N. Dynamics of Cave Development by Allogenic Water. Acta Carsologica, 30(2), 13-32. (2001)

23. Palmer, A.N. Cave Geology. Dayton, Ohio: Caves Books. (2007) 